University of Nebraska - Lincoln

DigitalCommons@University of Nebraska - Lincoln

USDA National Wildlife Research Center - Staff Publications
U.S. Department of Agriculture: Animal and Plant Health Inspection Service

April 1997

\title{
Carrion Seeking in Brown Tree Snakes: Importance of Olfactory and Visual Cues
}

John A. Shivik

Colorado State University, Ft. Collins, CO

Larry Clark

USDA/APHIS/WS National Wildlife Research Center, larry.clark@aphis.usda.gov

Follow this and additional works at: https://digitalcommons.unl.edu/icwdm_usdanwrc

Part of the Environmental Sciences Commons

Shivik, John A. and Clark, Larry, "Carrion Seeking in Brown Tree Snakes: Importance of Olfactory and Visual Cues" (1997). USDA National Wildlife Research Center - Staff Publications. 649.

https://digitalcommons.unl.edu/icwdm_usdanwrc/649

This Article is brought to you for free and open access by the U.S. Department of Agriculture: Animal and Plant Health Inspection Service at DigitalCommons@University of Nebraska - Lincoln. It has been accepted for inclusion in USDA National Wildlife Research Center - Staff Publications by an authorized administrator of DigitalCommons@University of Nebraska - Lincoln. 


\title{
Carrion Seeking in Brown Tree Snakes: Importance of Olfactory and Visual Cues
}

\author{
JOHN A. SHIVIK ${ }^{*}$ AND LARRY CLARK ${ }^{2}$ \\ ${ }^{1}$ Department of Biology, Colorado State University, Ft. Collins, \\ Colorado 80523 \\ ${ }^{2}$ USDA/APHIS/ADC/NWRC, Ft. Collins, Colorado 80524
}

\begin{abstract}
We performed field experiments to examine brown tree snake (Boiga irregularis) attraction to carrion. These snakes were attracted to carrion and entered traps baited with dead mice as readily as traps baited with live mice. Using the cues arising from both live and dead prey, we examined the relative importance of visual and chemical cues to brown tree snakes. With carrion lures, chemical cues alone were sufficient for attracting and capturing snakes, but with live prey lures visual cues were required to attract and capture brown tree snakes. Our study presents the first experimental field evidence showing carrion to be attractive to an ophidian predator and suggests that the relative importance of chemical and visual sensory stimuli to brown tree snakes is context-specific. J. Exp. Zool. 279:549-553, 1997. () 1997 Wiley-Liss, Inc.
\end{abstract}

Visual and chemical stimuli provide critical information to snakes about the type and location of prey. The importance of one stimulus over another varies according to the species of snake and the context of the stimulus. For example, chemical cues stimulate appetitive behavior in garter snakes and rattlesnakes (Thamnophis spp. and Crotalus spp.) (Burghardt, '69; Burghardt et al., '88; Chiszar et al., '90; Cowles and Phelan, '58; Duvall et al., '90; Ford and Low, '84; Golan et al., '82; Heller and Halpern, '81). Gopher snakes (Pituophis catenifer) and rat snakes (Elaphe obsoleta) use visual and/or chemical cues to find arboreal prey (Eichholz and Koenig, '92; Neal et al., '93). Brown tree snakes may respond to olfactory cues, be primarily visually guided, or switch between modalities when cues are ambiguous (Chiszar et al., '88; Chiszar, '90; Fritts et al., '89; Lankford, '89). The relative importance of visual and olfactory stimuli to foraging brown tree snakes appears to be dependent upon which cues are simultaneously presented (Chiszar, '90), but recent data suggest that, at least for live prey, visual and odor cues act synergistically to promote foraging behaviors in brown tree snakes (Shivik, in press).

On Guam, the brown tree snake feeds on a variety of prey, as it does in its native range (Fritts, '88; Chiszar, '90). The diversity of prey taken by brown tree snakes reflects shifts in diet as snakes grow; smaller size brown tree snakes prey upon lizards and lizard eggs, while large snakes prey primarily on mammals, birds, and bird eggs (Savidge, '88). Rodda ('92) reported that these snakes actively search for and ambush prey while residing in the lower layers of the forest canopy but that they will move to the ground when arboreal prey in an area are exterminated. Mildly venomous, the brown tree snake kills by constriction (Rochelle and Kardong, '93), but the snake is an aggressive predator. It is responsible for the extinction of numerous avian species on Guam (Savidge, '87).

Efforts to control brown tree snake populations are being carried out on Guam by the US Department of Agriculture, Animal Damage Control to reduce the risk of accidentally transporting this species to other islands (USDA, '96). An important tool in this effort is the use of snake traps baited with live mouse lures (Linnell et al., in press). During the course of the US Department of Agriculture's trapping program, we noted that the mice used as lures would, upon occasion, die and that traps containing dead mice would often capture snakes. Did these captures represent an uncommon opportunistic exploitation of a potential food source, or does attraction to carrion represent a broader pattern of snake foraging behavior? If carrion is attractive to brown tree snakes,

*Correspondence to: John A. Shivik, Department of Biology, Colorado State University, Ft. Collins, CO 80523. Email: jshivik@ lamar.colostate.edu

Received 7 November 1996; revision accepted 16 July 1997. 
it might be possible to develop an effective artificial attractant based on carrion odors.

The amount of carrion in the diet of snakes is thought to be inconsequential, unknown, or not acknowledged (Wright and Wright, '57; Porter, '72; Behler and King, '79; Mushinsky, '87; Shine, '91; Arnold, '93; Zug, '93). In general, snakes are not thought to forage for carrion but only to consume it in opportunistic or husbandry situations (Mattison, '95). The only snake thought to occasionally eat carrion is the cottonmouth (Agkistrodon piscivorous) (Gasc, '94). However, Crotalus spp. prefer dead prey (Cowles and Phelan, '58) because viperid predatory behavior involves envenomating, tracking, and finally consuming dead prey items. Thus, such venomous predators are believed to be more inclined to scavenge than species that kill prey by constriction (Patten and Banta, '80; Gillingham and Baker, '81; Lillywhite, '82; Diller, '90). However, nonvenomous colubrid snakes, which kill by constriction, have also been observed to eat carrion (Bedford, '91; Norton, '93; Mattison, '95). In general, snakes are thought not to actively forage for carrion because they are poorly equipped for the task compared with avian and mammalian species (Mattison, '95). In this study, we experimentally quantified the attraction to carrion by wild brown tree snakes and examined the relative importance of vision and olfaction in the context of foraging for live or dead prey.

\section{MATERIALS AND METHODS}

Two field experiments were conducted. One experiment was designed to determine whether brown tree snakes are attracted to carrion. Another experiment was performed to describe the importance of visual and odor cues in attracting brown tree snakes to live or decomposing prey. For both experiments, we used wire mesh minnow traps fitted with one-way doors and placed traps $20 \mathrm{~m}$ apart (Linnell et al., in press). Trap lines were established in forest edge along roads and trails near Tarague Beach, Guam. To prevent snakes from eating lures, we enclosed the lures within hardware cloth boxes $(7 \times 7 \times 20 \mathrm{~cm}$ boxes of $6 \mathrm{~mm}$ mesh) before placing them inside traps. To minimize extraneous biological odors, all traps and bait boxes were cleaned with a high-pressure water spray and then soaked in a 1:60 bleach:water solution for $\geq 2 \mathrm{~h}$. Traps were sun-dried before baiting and placement.

We ran each trap line for two nights, and each line contained ten traps/treatment type (randomly ordered). Traps were checked every morning, but, because each trap on each trap line was set for two nights in one location, all trap nights were not independent. Therefore, the sample unit was the mean capture rate at each trap location and not an individual trap night. The capture rate was a measure of both a snake's ability to detect a lure as well as a snake's interest (i.e., foraging behavior intense enough to result in trap entry) in the lure. We used analysis of variance to detect differences in capture rate between treatments. Statistical assumptions of the ANOVAs were evaluated using residual plots, and multiple comparisons were made using the Tukey procedure (Ott, '93).

To determine if wild brown tree snakes were attracted to carrion, we ran four trap lines during March and April 1997 at the Guam study area. The treatments were traps baited with a live mouse (a positive control), a quartered and decomposing dead mouse, or an empty trap (a negative control). Mice were euthanized in the early afternoon before trap placement according to National Wildlife Research Center (NWRC) guidelines (SOP WRC-128.R4), and trapping was performed with the approval of NWRC (QA479) and Colorado State University (95-247A-01) animal care and use committees. We recorded nightly captures, and all captured snakes were removed from the study area.

To determine the attractiveness of visual and odor cues of live and dead mice to brown tree snakes, we placed three trap lines during March and April 1996 in the Guam study area. We assessed the capture rates of live mice (the positive control), dead mice, live mice visually obscured, and dead mice visually obscured. Dead mice were euthanized in the early afternoon, as described above, but were left whole. Mice were visually obscured by wrapping black felt around the lure holder such that the mouse was not visible, but odors could permeate the fabric.

\section{RESULTS}

During 240 trap nights (120 trap stations), we captured 54 brown tree snakes using live mice, quartered dead mice, and empty traps. We detected a difference in capture rate by lure type $(P<0.001)$ (Fig. 1). Live mice and quartered dead mice were more attractive to brown tree snakes than empty traps ( $P=0.001$ and 0.003 , respectively).

We examined the likelihood that the capture of a snake during the first night's trapping influenced the capture of a snake during the second night's trapping. Eleven trap stations captured 


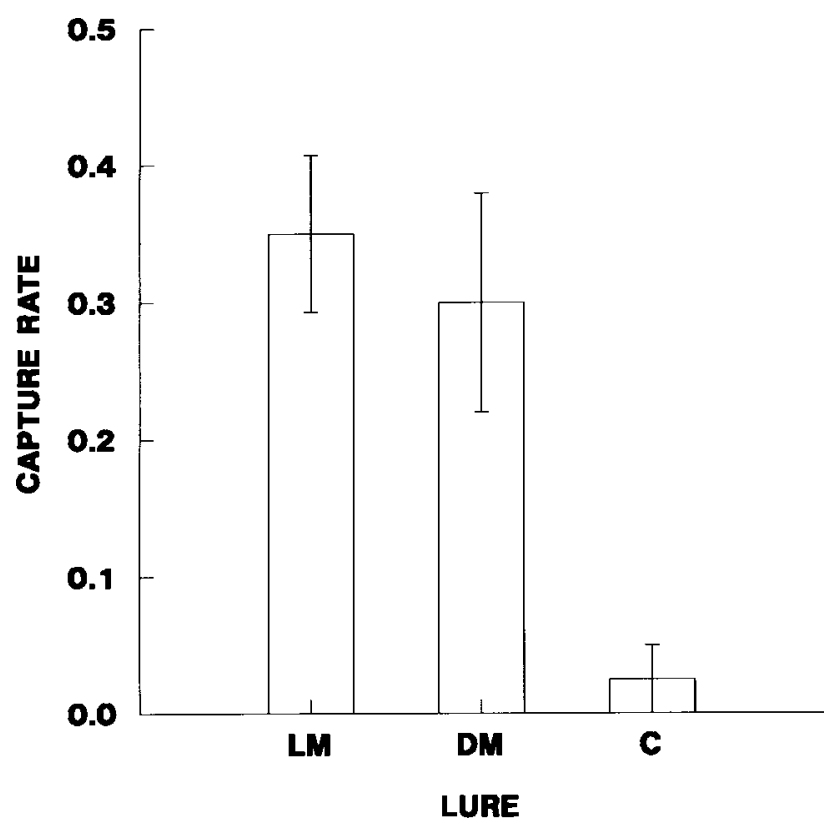

Fig. 1. Capture rates of brown tree snakes on Guam by lure type. C, empty control trap; DM, quartered dead mouse; LM, live mouse. Error bars represent one standard error. Sample sizes were 40 trap locations per treatment.

snakes on night 1 but not night 2 . However, 19 trap stations captured snakes on night 2 but not night 1 . Therefore, we found no evidence that a capture on night 1 increased the probability of a capture on night $2\left(\chi^{2}=2.511, P=0.113\right)$. There was no apparent attraction of snakes to traps that had previously held snakes.

For the test of visually apparent and visually obscured live and dead prey, we captured 97 brown tree snakes during 240 trap nights (120 trap stations). We detected a difference in capture rate by bait type $(P=0.019)$. Dead mice and dead mice obscured captured more brown tree snakes than live mice obscured ( $P=0.047$ and 0.023 , respectively). When visually obscured, live mice lost most of their effectiveness, but dead mice did not (Fig. 2).

\section{DISCUSSION}

These data present the first experimental field evidence of a snake being attracted to decomposing prey. In these experiments, brown tree snakes were attracted to decomposing and quartered mice that bore little resemblance to a living mouse, as gauged from human eyes and olfaction.

Reports of carrion foraging by snakes have been met with some resistance (Hammerson, '81; Patten, '81), and rare mention of carrion as a food source in herpetological texts leads one to believe

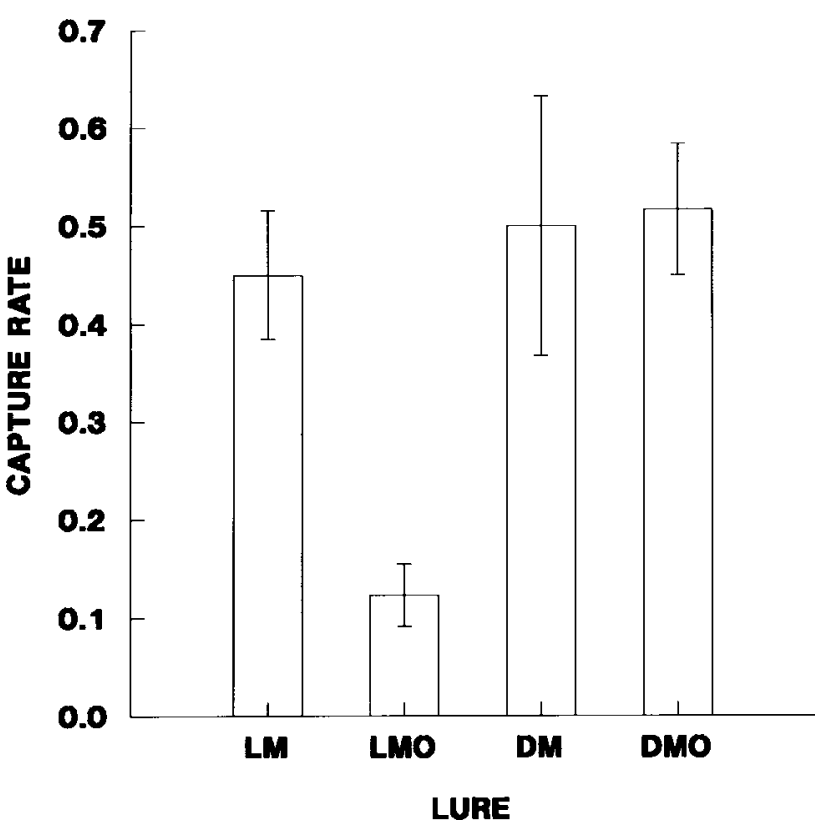

Fig. 2. Capture rates of brown tree snakes on Guam by stimulus presented. $\mathrm{DM}=$ dead mouse; $\mathrm{DMO}=$ dead mouse, visually obscured; LM, live mouse; LMO, live mouse, visually obscured. Error bars represent one standard error. Sample sizes were 30 trap locations per treatment.

that it is not an important food resource for snakes in general (Wright and Wright, '57; Porter, '72; Behler and King, '79; Mushinsky, '87; Shine, '91; Arnold, '93; Zug, '93). Reports of carrion feeding are generally viewed as curiosities and aberrant foraging behavior. Notwithstanding the popular belief that carrion is not an important food source for snakes, scavenging is anecdotally reported for viperids (Wharton, '66; Patten and Banta, '80; Gillingham and Baker, '81; Lillywhite, '82; Diller, '90; Hamel, '96) and colubrids (Bedford, '91; Norton, '93; Mattison, '95). Ours is the first field study to experimentally show that a snake is attracted to carrion and that the attractiveness of decomposing prey is similar to that of live prey. The number of anecdotal reports, combined with our field experiments, suggests that carrion feeding by snakes may be much more common than widely believed.

The brown tree snake is a colubrid that is thought to primarily rely on constriction to subdue and kill prey; the mechanism proposed that explains viperid interest in carrion (i.e., they are used to previously envenomated and long-dead animals [Patten and Banta, '80; Gillingham and Baker, '81; Lillywhite, '82; Diller, '90]) does not apply. As with predators of various other phylogenies (e.g., Canis, Haliaeetus, Chelydra), carrion 
can provide an important food resource to ophidian predators. Snakes are likely to actively (albeit not exclusively) search for and eat carrion. For both active foragers and sit-and-wait predators, finding prey, whether live or dead, is an opportunistic event. However, the decreased handling time involved with ingesting carrion improves its cost:benefit ratio and will favor its inclusion in the diet of all snakes.

The presence of a visual cue had no bearing on the attractiveness of dead prey but was very important for live prey because obscured dead prey were significantly more attractive to brown tree snakes than visually obscured live prey. Thus, we infer that odor was an important sensory cue used to locate carrion. In contrast, the loss of the visual cue for live mice lures resulted in reduced trap success. This observation indicates that vision is an important sensory system modulating appetitive foraging behavior for locating live prey. These observations indicate that the relative importance of vision and olfaction to foraging brown tree snakes is context-specific in terms of the stimuli presented (Chiszar, '90). For example, the presence of odors characteristic of live prey signal that a potential prey item was at one time at a given location. However, odors left by live prey do not ensure that the prey item is still nearby. Thus, for live prey, odor cues may increase appetitive behavior in a snake, but visual cues are needed to fully motivate active foraging. If carrion odors are present (e.g., emanating from a hole), it is highly likely that a carcass is still within the hole. Thus, if carrion is an acceptable food, odor alone should be a sufficiently potent cue to promote heightened appetitive behavior.

Alternatively, carrion odor may be "louder" and simply provide a more long distance signal to foraging snakes than live mice, which are best found visually. Under either hypothesis, the conclusion remains that brown tree snakes are attracted to carrion and that odor alone is a sufficient stimulus to draw them to it. We hypothesize that, upon detecting carrion odors, both active foragers and sit-and-wait foragers will search for carrion; only in the context of live-prey trails will sit-and-wait predators assume an ambush posture.

Snakes may be unable to effectively compete with many mammalian avian scavengers for the carcasses of large animals (Mattison, '95). However, snakes are better suited to probe cavities where small prey species find refuge and are likely to die from causes other than predation. The carrion resource that small prey species provide is likely to be exploited by many snake species, and the importance of the resource is a subject requiring further study.

\section{ACKNOWLEDGMENTS}

We thank P.J. Savarie and J.E. Brooks for assistance in the field and M.A. Linnell, M.E. Pitzler, D. Rodriguez, and H. Hirsh for logistical assistance on Guam. We thank R. Bruggers and A.K. Holloway for reviews of an earlier version of the manuscript. This project was conducted with funds provided to the National Wildlife Research Center and the Department of Biology, Colorado State University, by the US Department of Defense under DOD MIPR-064-95.

\section{LITERATURE CITED}

Arnold, S.J. (1993) Foraging theory and prey-size-predatorsize relations in snakes. In: Snakes: Ecology and Behavior. R.A. Seigel and J.T. Collins, eds. McGraw-Hill, New York, pp. 87-115.

Bedford, G. (1991) Record of road kill predation by the fresh water snake (Tropidonophis mariii). Herpetofauna, 21:35-36.

Behler, J.L., and F.W. King (1979) National Audubon Society Field Guide to North American Reptiles and Amphibians. Alfred A. Knopf, New York.

Burghardt, G.M. (1969) Comparative prey-attack studies in newborn snakes of the genus Thamnophis. Behaviour, 33:77-114.

Burghardt, G.M., S.E. Goss, and F.M. Schell (1988) Comparison of earthworm- and fish-derived chemicals eliciting prey attack by garter snakes (Thamnophis). J. Chem. Ecol., 14:855-880.

Chiszar, D.D. (1990) The behavior of the brown tree snake: A study in applied comparative psychology. In: Contemporary Issues in Comparative Psychology. D.A. Dewsbury, ed. Sinauer Associates Inc., Sunderland, MA, pp. 101-123.

Chiszar, D.D., K. Kandler, and H.M. Smith (1988) Stimulus control of predatory attack in the brown tree snake (Boiga irregularis) 1. Effects of visual cues arising from prey. Snake, 20:151-155.

Chiszar, D.D., T. Melcer, R. Lee, C.W. Radcliffe, and D. Duvall (1990) Chemical cues used by prairie rattlesnakes (Crotalus viridis) to follow trails of rodent prey. J. Chem. Ecol., 16:79-86.

Cowles, R.B., and R.L. Phelan (1958) Olfaction in rattlesnakes. Copeia, 1958:77-83.

Diller, L.V. (1990) A field observation on the feeding behavior of Crotalus viridis lutosus. J. Herpetol., 24:95-97.

Duvall, D., D. Chiszar, W.K. Hayes, J.K. Leonhardt, and M.J. Goode (1990) Chemical and behavioral ecology of foraging in prairie rattlesnakes (Crotalus viridis viridis). J. Chem. Ecol., 16:87-101.

Eichholz, M.W., and W.D. Koenig (1992) Gopher snake attraction to birds' nests. Southwest. Nat., 37:293-298.

Ford, N.B., and J.R. Low Jr. (1984) Sex pheromone source location by garter snakes: A mechanism for detection of direction in nonvolatile trails. J. Chem. Ecol., 10:1193-1199.

Fritts, T.H. (1988) The Brown Tree Snake, Boiga irregularis, a Threat to Pacific Islands. US Fish and Wildlife Service, Biological Report 88 (31). US Fish and Wildlife Service, Washington, DC. 
Fritts, T.H., N.J. Scott Jr., and B.E. Smith (1989) Trapping Boiga irregularis on Guam using bird odors. J. Herpetol., 23:189-192.

Gasc, J. (1994) Predation and nutrition. In: Snakes: A Natural History. R. Bauchot and H. Chaumeton, eds. Sterling Publishing Company, New York, pp. 108-121.

Gillingham, J., and R. Baker (1981) Evidence for scavenging behavior in the western diamondback rattlesnake (Crotalus atrox). Zeit. Fur Tierpsychol., 55:217-227.

Golan, L., C. Radcliffe, T. Miller, B. O'Connell, and D. Chiszar (1982) Trailing behavior in prairie rattlesnakes (Crotalus viridis). J. Herpetol., 16:287-293.

Hamel, P.B. (1996) Agkistrodon piscivorous leucostoma (Western cottonmouth) carrion feeding. Herpetol. Rev., 27:143.

Hammerson, G.A. (1981) Opportunistic scavenging by Crotalus ruber not field proven. J. Herpetol., 15:125.

Heller, S., and M. Halpern (1981) Laboratory observations on conspecific and congeneric scent trailing in garter snakes (Thamnophis). Behav. Neural Biol., 33:327-377.

Lankford, J.D. (1989) Stimulus control of foraging in brown tree snakes (Boiga irregularis) J. Colo.-Wyo. Acad. Sci., 21:12 (abstract).

Lillywhite, H. (1982) Cannibalistic carrion ingestion by the rattlesnake, Crotalus viridis. J. Herpetol., 16:95.

Linnell, M.A., R.M. Engeman, M.E. Pitzler, M.O. Watton, G.F. Whitehead, and R.C. Miller (in press) An evaluation of two designs of stamped metal trap flaps for use in operational trapping of brown tree snakes (Boiga irregularis). Snake.

Mattison, C. (1995) The Encyclopedia of Snakes. Facts on File, New York.

Mushinsky, H.R. (1987) Foraging ecology. In: Snakes: Ecology and Evolutionary Biology. R.A. Seigel, J.T. Collins, and S.S. Novak, eds. McGraw-Hill, New York, pp. 302-334.

Neal, J.C., W.G. Montague, and D.A. James (1993) Climbing by black rat snakes on cavity trees of red-cockaded woodpeckers. Wildl. Soc. Bull., 21:160-165.
Norton, R.L. (1993) Alsophis portoricensis richardi (Ground snake) feeding. Herpetol. Rev., 24:34.

Ott, R.L. (1993) An Introduction to Statistical Methods and Data Analysis. Duxbury Press, Belmont, CA.

Patten, R.B. (1981) Author's reply on road killed Dipodomys. J. Herpetol., 15:126.

Patten, R.B., and B.H. Banta (1980) A rattlesnake, Crotalus ruber, feeds on a road-killed animal. J. Herpetol., 14:111-112.

Porter, K.R. (1972) Herpetology. W.B. Saunders, Philadelphia. Rochelle, M.J., and K.V. Kardong (1993) Constriction versus envenomation in prey capture by the brown tree snake, Boiga irregularis (Squamata: Colubridae). Herpetologica, 49:301-304.

Rodda, G.H. (1992) Foraging behaviour of the brown tree snake, Boiga irregularis. Herpetol. J., 2:110-114.

Savidge, J.A. (1987) Extinction of an island forest avifauna by an introduced snake. Ecology, 68:660-668.

Savidge, J.A. (1988) Food habits of Boiga irregularis, an introduced predator on Guam. J. Herpetol., 22:275-282.

Shine, R. (1991) Australian snakes: A natural history. Cornell University Press, Ithaca, NY.

Shivik, J.A. (in press) Brown tree snake response to visual and olfactory cues. J. Wildl. Manage. 62:in press.

USDA (1996) Brown Tree Snake Control Activities on Guam. Environmental Assessment. United States Department of Agriculture, Washington, DC.

Wharton, C.H. (1966) Reproduction and growth in the cottonmouths, Agkistrodon piscivorus Lacepede, of Cedar Keys, Florida. Copeia, 1966:149-161.

Wright, A.H., and A.A. Wright (1957) Handbook of Snakes of the United States and Canada. Comstock Publishing Associates, Ithaca, NY.

Zug, G.R. (1993) Herpetology: An Introductory Biology of Amphibians and Reptiles. Academic Press, San Diego, CA. 